\title{
CENTRAL VENOUS PRESSURE IN RELATION TO CARDIAC “COMPETENCE," BLOOD VOLUME AND EXERCISE
}

\author{
By E. M. LANDIS, E. BROWN, ${ }^{1}$ M. FAUTEUX, ${ }^{2}$ aNd C. WISE 3 \\ (From the Department of Physiology and the Laboratory of Surgical Research, \\ Harvard Medical School, Boston)
}

(Received for publication October 31, 1945)

The mechanism by which venous pressure is elevated in human heart disease, and the exact relation between venous pressure and the plethora of late cardiac failure are still uncertain. Starling, primarily from his results with the heart-lung preparation (1), suggested the following sequence :

Cardiac failure $\rightarrow$ elevated venous pressure $\rightarrow$ accumulation of blood in the large veins $\rightarrow$ compensatory arteriolar constriction $\rightarrow$ anoxia of bone marrow $\rightarrow$ increase in blood volume.

This hypothesis with its tacit assumption that "back pressure" occurs in the intact animal, as it does more clearly in the heart-lung preparation, has been challenged recently by Starr, Jeffers and Meade (2), and by Warren and Stead (3) who relate venous pressure to cardiac failure essentially as follows :

"Impaired cardiac function" $\rightarrow$ decreased renal excretion of sodium and water (mechanism unknown $) \rightarrow$ increased blood volume $\rightarrow$ elevated venous pressure.

Starr et al, (2) observed that acute damage of the right ventricle failed to elevate significantly the venous pressures of dogs, but these studies were limited to the resting state. Warren and Stead (3) found in cardiac patients, also during rest, that administering water and sodium chloride increased blood volume before venous pressure rose significantly. They concluded that the earliest manifestation of cardiac insufficiency is a retention of fluid, the cause of which is not clear, associated with an increase of blood volume. This plethora or hypervolemia is said then to be responsible for the elevated venous pressure which

\footnotetext{
1 Research Fellow in Physiology, Commonwealth Fund.

2 Henry E. Warren Fellow in Surgery.

3 Research Fellow in Physiology, Baruch Committee on Physical Medicine.
}

is believed, therefore, to be a remote and indirect, rather than an immediate, result of right ventricular failure.

It seems unwise, however, to draw far-reaching conclusions of this type from venous pressures which have been measured only at rest. It has been shown repeatedly in the heart-lung preparation that the pressure and volume dynamics of a damaged heart cannot be distinguished from those of a normal heart if the imposed burden (volume or pressure) is small, whereas clear differences appear only when the burden exceeds the heart's "competence" to perform work. Thus Krayer (4) has demonstrated that the auricular pressure of a moderately damaged heart remains much lower than the pressure in the venous reservoir, until the volume of blood entering the heart is made great enough to tax the heart's "competence" to do work (Leistungsfähigkeit). Only when this "competence" is approached or exceeded does blood pressure in the auricle rise to aproach that exerted by the blood in the venous reservoir.

A quantitatively similar gradient between peripheral and auricular venous pressures was found (5) in auricular catheterizations of normal human beings. In some patients with cardiac damage normal peripheral venous pressures at rest were associated with auricular pressures which were considerably higher than normal. Hence in these patients, as in the failing heart-lung preparation, the normal gradient tended to disappear.

In addition, patients with "compensated heart disease" commonly have a normal venous pressure at rest when venous return is small, but often exhibit abnormally high venous pressures during, and for some time after, exercise when venous return is greater and the work demanded of the heart is correspondingly increased (6 to 10). While admitting the obvious and important differences between the conditions existing in the heart- 
lung preparation and in the closed circulation of the intact animal, it still seems probable, a priori, that the recording at rest of a venous pressure within the normal range gives no assurance that cardiac function and venous pressure will remain normal during exercise. The origin of impaired renal function, and of plethora, in chronic congestive failure may possibly be related to many brief and intermittent elevations of venous pressure, occurring whenever muscular activity imposes a burden which approaches or exceeds cardiac "competence."

The essential questions are: (1) Granted that acute experimental damage of the right ventricle does not elevate venous pressure during rest, will muscular activity, by imposing a heavier load on the heart, raise venous pressure to a greater degree than similar exercise does in normal animals? (2) If muscular activity characteristically elevates venous pressure in the presence of reduced cardiac "competence" and normal blood volume, will a simple increase in blood volume per se duplicate this effect when the heart is normal?

The studies described below extend in anesthetized dogs the observations described $(2,3)$ to include $(a)$ the effects of cardiac damage on venous pressure during muscular activity as well as during rest and $(b)$ the effects on venous pressure of increasing blood volume, also during both activity and rest. In these dogs impaired cardiac function did not increase resting venous pressure; but exercise revealed a reduced cardiac competence by the rise of venous pressure it produced. Simple plethora, produced by small or huge transfusions of whole blood, even while elevating venous pressure very temporarily during rest, did not per se cause exercise to elevate venous pressure still further in the fashion which appears to be highly characteristic of reduced cardiac "competence" in the intact animal as in the heart-lung preparation. Reasons will be advanced for suggesting that this rise of venous pressure during exercise may be the first indication of reduced cardiac competence and may be responsible for arteriolar constriction, impaired renal function, increased activity of bone marrow, and finally plethora or hypervolemia.

\section{METHODS}

Dogs weighing from 12 to $17 \mathrm{kgm}$. were anesthetized by injecting into their lumbar muscles, in divided doses, a total of $1 \mathrm{ml}$. per $\mathrm{kgm}$. of a solution containing 3 per cent morphine, 4.2 per cent chloralose, and 50 per cent urethane. Additional maintenance doses of $0.1 \mathrm{ml}$. per $\mathrm{kgm}$. were injected into the axillary spaces or the lumbar muscles at intervals of one hour or more as required.

Arterial blood pressure was recorded continuously on smoked paper by mercury manometer or, more usually, by a membrane manometer of the Hürthle type, from the left carotid artery using heparin as an anticoagulant. Venous blood pressure was also recorded continuously through a freshly paraffined curved glass cannula inserted via the right external jugular vein into the superior vena cava close to the heart. Both systems were arranged so that "zero pressure" corresponded to the midpoint of the antero-posterior diameter of the chest. Continued patency of the venous pressure system was assured by washing out the cannula at intervals of 2 to 5 minutes with 1 or $2 \mathrm{ml}$. of Ringer's solution containing 10 units of heparin per ml. Each "washout" was recorded on the smoked paper. Heart rates were computed from electrocardiograms taken by an ink-writing oscillograph, or occasionally by direct counts.

To induce exercise metallic lead electrodes, measuring 3 by $6 \mathrm{~cm}$., were sewed by their perforated edges to the inner and outer surfaces of each thigh and upper foreleg. Electrode paste was applied liberally between the skin and the lead surface to assure good conductivity. These four pairs of electrodes were connected independently to the secondaries of four inductoria, the primaries of which were activated intermittently and simultaneously from a storage battery by means of a motor-driven circuit breaker. The resulting intermittent stimulation produced a strong tetanic contraction of the major muscles of all four legs, sustained for 0.45 second out of each second.

Three methods were used to embarrass cardiac function, viz.: (a) ligation of certain coronary arteries, $(b)$ production of auricular fibrillation, and (c) 'elevation of pericardial pressure (cardiac tamponade). Arterial pressure, venous pressure, electrocardiograms and heart rates were recorded during operative procedures to detect any unusual changes induced by surgery. With a single exception, noted below in Figure 1F, the observations upon which this report is based were limited to the pre-operative period (for control studies) and to the post-operative period after the chest had been closed and the animals had been breathing normally and spontaneously for at least twenty minutes.

(a) Ligation of coronary arteries. After the control response to exercise had been recorded the dog was laid on the left side, the fourth rib removed and the thorax opened under artificial respiration. Through a wide incision of the pericardium the chosen coronary vessels were dissected free and ligated. The chest was then closed and aspirated; the dog was returned to dorsal decubitus, with legs outspread, and artificial respiration was stopped. After the establishment of regular spontaneous breathing and an allowance of twenty or more minutes for recovery, the standard exercise was induced again for 5 minutes. After another rest period of 20 minutes a second bout of 
exercise was induced either for the usual period of $5 \mathrm{~min}$ utes or, in some cases, was continued until death ensued.

The heart was then removed, so that the location and completeness of occlusion could be confirmed by introducing a probe into the aortic orifice of the ligated artery until blocked by the ligature. Finally the coronary vessels were injected by the technique of Fauteux (11) to identify which of the many possible anastomotic connections were present in each instance.

(b) Auricular fibrillation. Two methods were used, one of which (surgical) required opening the chest whereas the other avoided thoracic surgery with its associated trauma and loss of blood.

The surgical method (12) involved stitching the bare ends of two otherwise insulated fine silver wires to the surface of the right auricle through an incision in the chest wall and a small hole in the pericardium. The chest wound was then closed as usual except that the two insulated wires were brought out between layers in zigzag fashion and attached to the secondary of an ordinary inductorium. After closure of the chest and aspiration of remaining intrapleural air, the dogs were permitted to resume spontaneous respiration and were placed again in dorsal decubitus with legs outstretched so that the effects of auricular fibrillation and of standard exercise, each alone and both together, could be tested for comparison.

In the non-operative procedure a fine silver wire insulated except for its terminal $2 \mathrm{~cm}$., which were uncovered and tightly coiled into a small spring, was threaded through a glass tube via the left jugular vein into the right auricle of heparinized dogs with the aid of $x$-ray fluoroscopy. The coil was arranged so that when pushed beyond the end of the glass tube its natural springiness would bring it into contact with the inner surface of the right auricle. The other electrode was introduced per os into the esophagus far enough to bring the stimulating surface behind the base of the heart. This stimulating surface consisted of a copper rod which projected about 3 centimeters from a heavy rubber tube. Wires from both electrodes were attached to a stimulator, usually an ordinary inductorium.

(c) Cardiac tamponade. The chest having been opened as usual under artificial respiration, a minute incision was made in the pericardium. A small, rubber covered, glass cannula filled with Ringer's solution was introduced, sewed tightly, and connected by stiff rubber tubing to a water manometer, a calibrated reservoir bottle and a syringe through a 3-way stopcock. After testing the system for leakage by addition and aspiration of Ringer's fluid, the chest wound was closed tightly around the tube leading to the cannula, residual air was aspirated from the thorax and artificial respiration was stopped. As in other procedures observations were begun only after the animal had been breathing spontaneously for 20 minutes or more.

Blood volume was increased by measured transfusions of whole blood or infusions of Ringer's fluid. For transfusions blood was removed, on the day of the experiment, from the carotid arteries of donor dogs. As blood entered the collecting flask, anticoagulant was added to each 100 ml. progressively in the amount of $4 \mathrm{ml}$. of a solution containing 8 per cent sodium citrate and $0.1 \mathrm{ml}$. (100 units) of liquid heparin (Connaught). This blood was pooled, kept at room temperature for not more than four hours and then warmed to body temperature prior to injection into the left jugular vein except in one instance when a femoral vein was used.

In one series of observations a volume of blood equal to 50 per cent of the calculated total blood volume of the animal was injected at a uniform rate of $50 \mathrm{ml}$. per 30 seconds by using a $50 \mathrm{ml}$. syringe connected to the venous cannula and the reservoir bottle through a 3-way stopcock. The use of the syringe made the injection slightly discontinuous because 5 seconds out of each 30 were required for refilling the syringe. On the other hand this method offered the advantage of making the transfusions accurate and uniform as to average rate and total volume.

In a second series, in a sense the converse of the first, venous pressure was maintained relatively constant at high predetermined levels for 15 to $\mathbf{4 5}$ minutes by infusing relatively huge volumes of whole blood or of Ringer's solution at whatever rate and in whatever total amount might be necessary. The largest possible cannula was inserted via the left jugular vein into the superior vena cava and connected by wide rubber tubing to a Mariotte bottle, which was calibrated for volumes up to $4500 \mathrm{ml}$. The height of the bottle above the mid-thoracic level determined the venous pressure which could be developed; the variable in this series being the rate of infusion. Both the rate of flow and the total volume of the fluid entering the circulation could be followed by means of calibrations on the Mariotte bottle and appropriate signals on the smoked record. The effects of exercise could then be studied $(a)$ at normal venous pressure and blood volume, and $(b)$ at abnormally high, sustained venous pressures due to plethora well beyond the physiological range.

\section{OBSERVATIONS}

\section{Effects of graded exercise induced in anes- thetized dogs}

Without operative procedures other than the simple insertion of arterial, tracheal and venous cannulae, the effects of graded exercise (one, two or four limbs, and 15 to 120 contractions per minute) were observed either in prolonged control studies, or as single control tests prior to opening the chest. A few representative single observations on different dogs are summarized in Table I to show primarily the general magnitude of changes in arterial blood pressure, central venous pressure and heart rate, as well as the variability of these changes from animal to animal.

Increasingly vigorous exercise, as would be expected, produced greater tachycardia and greater rise of arterial pressure but it is also obvious that 
TABLE I

Representative effects of 5 minute bouts of exercise; 1, 2 and 4 limbs; contracting at 4,2, 1 and $1 / 2$ second intervals

\begin{tabular}{|c|c|c|c|c|c|}
\hline \multirow{2}{*}{$\begin{array}{c}\text { Number } \\
\text { of limbs } \\
\text { con- } \\
\text { tracting }\end{array}$} & \multirow{2}{*}{$\begin{array}{l}\text { Con- } \\
\text { tractions } \\
\text { per } \\
\text { minute }\end{array}$} & \multicolumn{3}{|c|}{$\begin{array}{l}\text { Change from prior average resting } \\
\text { state produced by five } \\
\text { minutes' exercise }\end{array}$} & \multirow{2}{*}{$\begin{array}{l}\text { Approxi- } \\
\text { mate time } \\
\text { for heart } \\
\text { rate to } \\
\text { return to } \\
\text { resting } \\
\text { level }\end{array}$} \\
\hline & & $\begin{array}{c}\text { Mean } \\
\text { arterial } \\
\text { blood } \\
\text { pressure }\end{array}$ & $\begin{array}{l}\text { Central } \\
\text { venous } \\
\text { pressure }\end{array}$ & $\begin{array}{c}\text { Heart } \\
\text { rate }\end{array}$ & \\
\hline 1 & 60 & $\begin{array}{c}m m . H g \\
0\end{array}$ & $\begin{array}{c}\text { mm. water } \\
0\end{array}$ & $\begin{array}{c}\text { beats per } \\
\text { minute } \\
0\end{array}$ & $\min$. \\
\hline 2 & 60 & 0 & 0 & +6 & $20(?)$ \\
\hline 4 & 15 & +20 & $(+5)^{*}-5$ & +23 & 8 \\
\hline 4 & 30 & +10 & -10 & +26 & 5 \\
\hline 4 & 60 & $\begin{array}{r}+50 \\
0 \\
+50 \\
+10 \\
+20\end{array}$ & $\begin{array}{c}(+30) *-44 \\
-10 \\
-105 \\
0 \\
(+10)^{*}-40\end{array}$ & $\begin{array}{l}+102 \\
+122 \\
+195 \\
+107 \\
+56\end{array}$ & $\begin{array}{l}20+ \\
20+ \\
20+ \\
20+ \\
20+\end{array}$ \\
\hline 4 & 120 & +14 & -5 & +62 & $15+$ \\
\hline
\end{tabular}

* Figures in parentheses indicate transitory elevations of venous pressure with the first few contractions and lasting from 5 to 15 seconds only.

with similar intensity of exercise the quantitative responses in different animals varied widely. Anesthesia itself, or varying absorption of anesthetic, may have been partially responsible. In any case, differences in muscular development and in vigor of contractions made it advisable to base conclusions on comparisons between pairs of control and experimental observations in the same animal.

Resting heart rates were almost always between 70 and 100 per minute with exceptional rates up to 130 in a few animals. In all cases contractions of four limbs produced a significant, relative tachycardia with absolute rates in excess of 180 and often over 200 beats per minute. The slowness with which this tachycardia disappeared after exercise indicated that a significant burden had been imposed on the circulation. Lesser grades of exercise were insufficient to produce uniform and marked tachycardia, while increasing the contraction rate to 120 per minute offered no clear advantages. Hence the standard bout of exercise chosen consisted of contractions of four limbs, once per second, for 5 minutes, after a prior rest of at least 20 minutes.
In prolonged control observations consisting of six or more such bouts of exercise, separated by at least 20 minutes of rest, the acute changes produced by successive bouts were approximately similar until hyperthermia supervened. Each period of standard exercise elevated body temperature in the first three or four bouts by $0.2^{\circ}$ to $0.4^{\circ} \mathrm{C}$., after which the rise might become as much as $0.5^{\circ}$ or $1.0^{\circ} \mathrm{C}$. per bout. Normal animals died of hyperthermia with secondary circulatory failure rather than from circulatory failure per se. No dependence could be placed on observations made when body temperatures exceeded $40^{\circ} \mathrm{C}$.

It is probable that a rest of 20 minutes between bouts of exercise was not quite long enough to permit complete recovery because in addition to rising body temperature the resting heart rate increased slowly, and resting venous pressure tended to fall slightly, even though the acute change in successive bouts remained comparable in magnitude until exhaustion developed. For these reasons primary emphasis will be placed on comparing in each animal the acute changes produced $(a)$ by control exercise while cardiac function was normal, and $(b)$ by the first and second bouts of exercise induced after cardiac function had been interfered with, or blood volume had been increased.

\section{Ligation of coronary arteries: effect on venous pressure during rest and exercise}

After control observations on venous pressure during rest, and in 7 of 11 dogs also during exercise, the right coronary artery was ligated in 5 dogs, the circumflex artery in 2 and the right coronary artery with the ramus descendens or its main branch in 4 . Table II summarizes the results in these animals giving in each instance the site of ligation and the anastomoses revealed by post-mortem injection of the coronary arteries. Following the system used by Fauteux (11) type iii refers to anastomosis between the posterior branch of the circumflex artery and the ramus descendens; type iv to anastomoses between both posterior terminal branches of the right and left coronary arteries, and type $\mathrm{v}$ to anastomosis between the anterior branch of the right coronary artery and the ramus descendens. 
TABLE II

Effect of exercise on central venous pressure of dogs before and after ligation of coronary arteries

\begin{tabular}{|c|c|c|c|c|c|c|c|c|c|}
\hline \multirow{3}{*}{$\begin{array}{l}\text { Dog } \\
\text { no. }\end{array}$} & \multirow{3}{*}{$\begin{array}{l}\text { Site of ligation } \\
\text { (measured from aortic orifice) }\end{array}$} & \multirow{3}{*}{ Anastomoses } & \multicolumn{4}{|c|}{ Absolute venous pressures* } & \multicolumn{3}{|c|}{ Change in venous pressure produced } \\
\hline & & & \multicolumn{2}{|c|}{ Before ligation } & \multicolumn{2}{|c|}{ After ligation } & \multirow{2}{*}{$\begin{array}{l}\text { By } \\
\text { operation } \\
\text { and } \\
\text { ligation } \\
\text { (resting) }\end{array}$} & \multicolumn{2}{|c|}{ By exercise } \\
\hline & & & $\underset{\text { rest }}{\text { During }}$ & $\begin{array}{l}\text { During } \\
\text { exercise }\end{array}$ & $\begin{array}{l}\text { During } \\
\text { rest }\end{array}$ & $\begin{array}{l}\text { During } \\
\text { exercise }\end{array}$ & & $\begin{array}{l}\text { Before } \\
\text { ligation }\end{array}$ & $\begin{array}{l}\text { After } \\
\text { ligation }\end{array}$ \\
\hline $\begin{array}{r}9 \\
10 \\
12 \\
14\end{array}$ & $\begin{array}{l}\text { Rt. coronary, } 13 \mathrm{~mm} \text {. } \\
\text { Rt. coronary, } 14 \mathrm{~mm} \text {. } \\
\text { Rt. coronary, } 15 \mathrm{~mm} \text {. } \\
\text { Rt. coronary, } 12 \mathrm{~mm} \text {. }\end{array}$ & $\begin{array}{l}\text { iii, iv } \\
\text { iii, v } \\
\text { iii, iv } \\
\text { iv }\end{array}$ & $\begin{array}{c}m m . \mathrm{H}_{2} \mathrm{O} \\
+28 \\
+10 \\
+32 \\
+40\end{array}$ & $\begin{array}{c}m m . \mathrm{H}_{2} \mathrm{O} \\
+5 \\
-50 \\
-64 \\
-14\end{array}$ & $\begin{array}{c}m m . H: O \\
+20 \\
-28 \\
+12 \\
-10\end{array}$ & $\begin{array}{c}m m . \mathrm{H}_{2} \mathrm{O} \\
+50 \\
-8 \\
0 \\
(+40) \dagger \\
-20\end{array}$ & $\begin{array}{c}m m . \mathrm{H}_{2} \mathrm{O} \\
-8 \\
-18 \\
-20 \\
-50\end{array}$ & $\begin{array}{c}m m . \mathrm{H}_{2} \mathrm{O} \\
-23 \\
-40 \\
-96 \\
-54\end{array}$ & $\begin{array}{c}m m . \mathrm{H}_{2} \mathrm{O} \\
+30 \\
+20 \\
-12 \\
(+28) \dagger \\
-10\end{array}$ \\
\hline 29 & Rt. coronary, $19 \mathrm{~mm}$. & iv & +10 & -10 & \multicolumn{5}{|c|}{ Ventricular fibrillation -3 minutes after ligation } \\
\hline 7 & Circumflex, $40 \mathrm{~mm}$. & None & +30 & +20 & +8 & +40 & -22 & -10 & +32 \\
\hline 8 & Circumflex, $10 \mathrm{~mm}$. & iv & +20 & -10 & \multicolumn{5}{|c|}{ Ventricular fibrillation -13 minutes after ligation } \\
\hline 15 & $\begin{array}{l}\text { Rt. coronary, } 18 \mathrm{~mm} . \\
\text { Ramus descendens, } 30 \mathrm{~mm} \text {. }\end{array}$ & None & +12 & & \multicolumn{5}{|c|}{ Ventricular fibrillation -2 minutes after ligation } \\
\hline 16 & $\begin{array}{l}\text { Rt. coronary, } 19 \mathrm{~mm} . \\
\text { Ramus descendens, } 30 \mathrm{~mm} \text {. }\end{array}$ & iii, v & +100 & & +72 & +40 & -28 & & -32 \\
\hline 17 & $\begin{array}{l}\text { Rt. coronary, } 20 \mathrm{~mm} \text {. } \\
\text { Ramus descendens, } 29 \mathrm{~mm} \text {. }\end{array}$ & iii & +36 & & \multicolumn{5}{|c|}{ Ventricular fibrillation -5 minutes after ligation } \\
\hline 20 & $\begin{array}{l}\text { Rt. coronary, } 19 \mathrm{~mm} . \\
\text { Ramus descendens, } 29 \mathrm{~mm} \text {. }\end{array}$ & iii, iv & +39 & & +24 & +20 & -15 & & -4 \\
\hline
\end{tabular}

* Referred to mid-point of antero-posterior diameter of chest.

$\dagger$ After 20 minutes' exercise and prior to ventricular fibrillation.

The effects of ligating the same coronary vessels differed from animal to animal as might be expected from the recorded differences in anastomotic connections. Ventricular fibrillation occurred in 4 instances within 2 to 13 minutes after ligation while the animal was still in the resting state. As ventricular fibrillation began arterial pressure fell percipitously to zero while venous pressure rose with similar abruptness to $150 \mathrm{~mm}$. of water or more. This, however, represents an agonal rise of venous pressure and is not. relevant to the present question as to whether venous pressure can rise while arterial pressure remains at or near its normal level.

In the remaining 7 animals, interference with coronary circulation did not elevate the venous pressure during rest; in fact resting venous pressure after coronary ligation was less than the preoperative resting venous pressure by 8 to $50 \mathrm{~mm}$. water. This agrees with earlier observations by others $(13,2)$.

On the other hand, comparisons of venous pressures during exercise before and after ligation revealed important differences. Before ligation exercise lowered venous pressures acutely by between 10 and $96 \mathrm{~mm}$. water. The first few contractions in some instances produced a transient elevation lasting not more than 5 to 15 seconds, owing apparently to sudden increase of venous return by the initial simultaneous tightening of the muscles of all four extremities. This was soon followed by tachycardia, quicker and deeper respirations, and a reduction of venous pressure which was sustained (Figure 1A) or actually became progressively more marked (Figure 1D).

After ligation, exercise elevated venous pressure in 3 animals (e.g. Figure 1, B and C) by 30 , 20 , and $32 \mathrm{~mm}$. water. The magnitude of these 

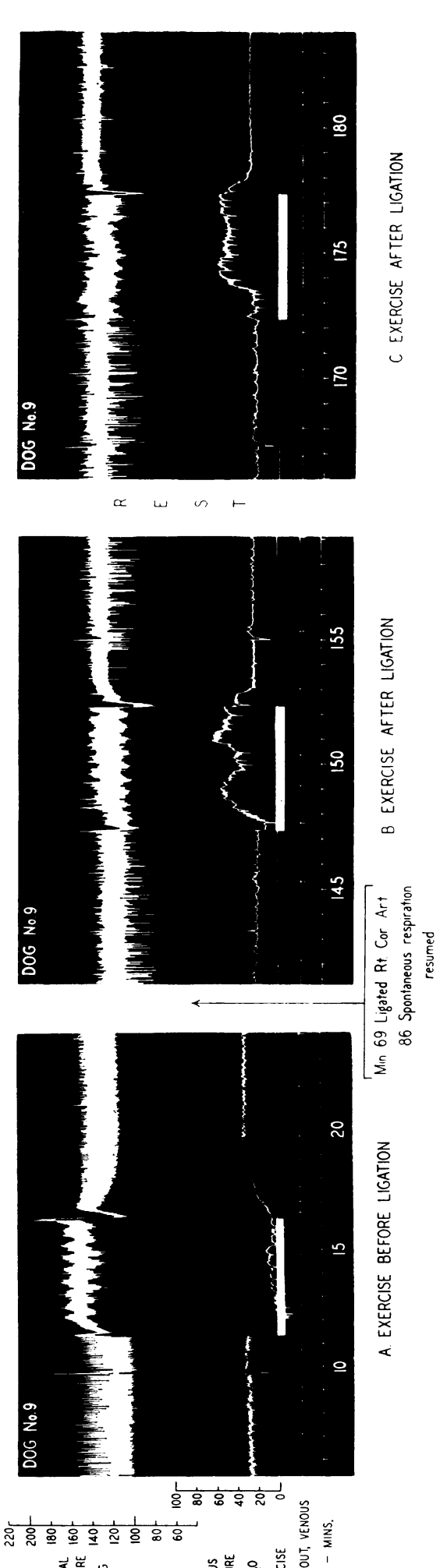

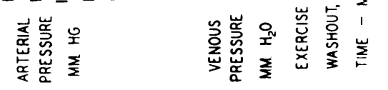
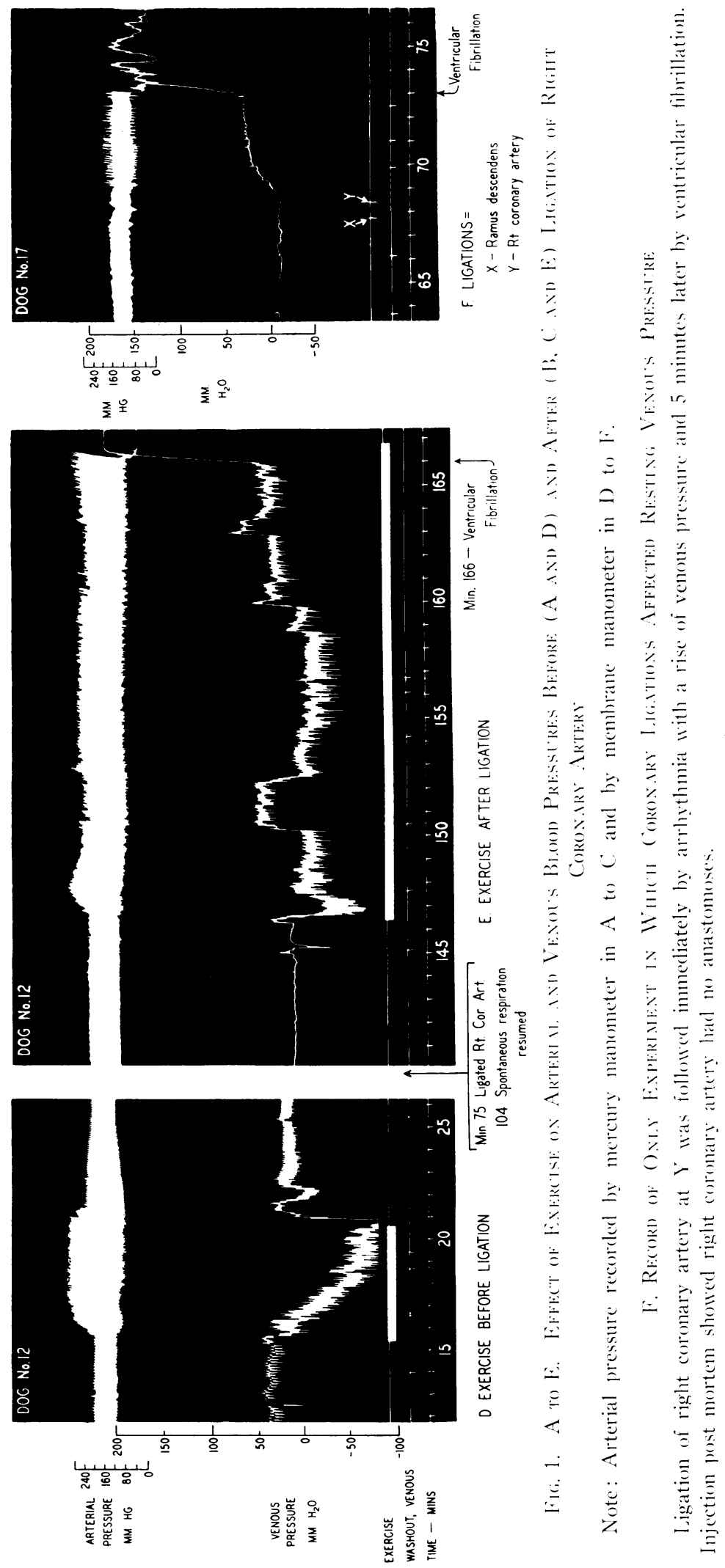
elevations was not great but it must be remembered that the blood loss and trauma of thoracic surgery would tend to reduce available blood volume and to diminish any possible increase of venous return produced by exercise. Moreover, even in those animals not showing an absolute elevation of venous pressure during exercise after ligation, the fall was always less pronounced than that observed during control exercise. Unfortunately, control figures are incomplete in 2 animals (no. 16 and 20) but for the remaining 5 the total algebraic differences between venous pressures during exercise before and after ligation amount to $+53,+60,+84,+44$, and $+42 \mathrm{~mm}$. water.

Before operation heart rates during rest ranged from 57 to 96 beats per minute; and after operation, also during rest, from 86 to 176 beats per minute. Control exercise, prior to operation, increased the heart rate by 50 to 195 beats per minute, the highest observed absolute rate being 252 beats per minute. Similar exercise, after operation and ligation of the coronary arteries, raised the heart rate from the higher resting levels by smaller increments, viz. by 16 to 86 beats per minute, the highest absolute rate being 236 beats per minute. These results, when compared singly or in the aggregate, were not related in any consistent fashion to the observed changes in venous pressure, which therefore cannot be ascribed to excessive tachycardia and incomplete filling of the right ventricle.

Arterial blood pressure did not necessarily fall as venous pressure rose with exercise. Figures $1 \mathrm{~A}, \mathrm{~B}, \mathrm{C}$ reproduce the record of $\operatorname{dog} 9$ to show (a) the unchanged resting venous pressure after ligation (compare initial sections of $1 \mathrm{~A}$ and $1 \mathrm{~B}$ ) and $(b)$ the effect of ligation on the circulatory response to exercise. Before ligation (Figure 1A) exercise was accompanied by a rise of arterial pressure and a fall of venous pressure. After ligation (Figure 1B) similar exercise led to a rise of venous pressure by $30 \mathrm{~mm}$. water associated with a relatively constant arterial pressure. Repetition of exercise after 20 minutes of rest gave essentially similar results (Figure $1 \mathrm{C}$ ).

Figures $1 \mathrm{D}$ and $1 \mathrm{E}$ have been included because $\operatorname{dog} 12$ was described with those in which venous pressure did not rise during exercise even after ligation, a conclusion which applies only to the first 5-minute period which was used routinely for comparison. Just at the end of the standard post-operative exercise it was observed that venous pressure rose sharply during a few seconds when frequent extrasystoles occurred. Exercise was therefore continued even after the arrhythmia ceased and for the next 20 minutes venous pressure rose irregularly, though systolic and diastolic arterial pressure (indicated by Hürthle manometer) remained relatively constant. Finally ventricular fibrillation produced the typical abrupt fall of arterial pressure and the usual agonal rise of venous pressure.

It has been mentioned that in all of the animals which survived long enough to be exercised, resting venoùs pressure was not elevated, indicating that right ventricular function was adequate for the resting state even though the burden of exercise might reveal impairment. In only one instance was an immediate rise of resting venous pressure observed (Figure $1 \mathrm{~F}$ ) and this followed a double ligation, of which the second involved a right coronary artery having no anastomotic connections detectable by later injection. This dog was included in Table II among the four dying of early ventricular fibrillation but in this single instance frequent extrasystoles preceded the fibrillation by a few minutes during which, with the animal at rest and the thorax open, venous pressure rose by $30 \mathrm{~mm}$. water without great reduction of mean arterial pressure. Ventricular fibrillation ensued within 3 minutes and the irregularities of the latter part of the pressure tracings were produced by cardiac massage in unsuccessful efforts $t$, ristore normal rhythm.

These findings suggest that acute interference with the blood supply of the right ventricle commonly failed to elevate resting venous pressure because in the more severely damaged hearts, ventricular fibrillation usually ensued before cardiac "competence" could be reduced to the point at which the heart was unable to handle the small venous return characteristic of the resting state. - In the survivors, with lesser reductions of cardiac "competence," resting venous pressure was normal but exercise revealed, through a rise of venous pressure, a decrease in the ability of the heart to handle adequately the increased venous return. The incidence of ventricular fibrillation and the unpredictability of anastomotic connections made it desirable to test the validity of these findings 
by using other methods of embarrassing the heart's action.

3. Auricular fibrillation. artificially induced; effects on contral a'chous pressure alone and combined aith exercise

Auricular fibrillation, a common clinical cause of both acute and chronic congestive failure, was produced (a) in 5 dogs by the surgical method (12) and (b) in $4 \operatorname{dogs}$ by a less traumatizing procedure. which did not require opening the chest. avoided blood loss. and left intrathoracic pressure and the pericardium completely undisturbed (see Methods). Evidence that true auricular fibrillation was produced consisted of (1) clirect inspection of the exposed heart during stimulation (in operated animals only). (2) recording of systolic and diastolic arterial pressures cluring stimulation on a rapidly moving drum, and (3) electrocardiograms recorded by ink-writing ascillograph immediately after stimulation ceased and before normal rhythm returned. Transient periods of auricular flutter with shifting block were identified on several occasions. In a few early experiments a conclenser stimulator was used to vary the voltage. duration and irequency of stimuli; but no advantage could be observed and the simple inductorium was used routinely thereafter. During auricular fibrillation ventricular rates of 172 to $44+$ per minute were observed in dogs prepared by the surgical method, and rates of 200 to 300 per minute were found in the monerated $\operatorname{logs}$.

Figure 2 illustrates one of the more striking examples of the acute changes in central venous pressure produced (a) first by exercise alone then with superimposed auricular fibrillation, (b). first by fibrillation alone; then with superimposed exercise, and $(c)$ by exercise alone 20 minutes later. The record is striking because, by chance, fibrillation alone produced no significant change in venous pressure. indicating that arrhythmia for so cird not, in this instance, reduce the "competence" of the heart to the point where "back pressure" could be identified at rest. Superimposed exercise, however, made this reduction of "competence" obvious by increasing the work demanded of the heart and by raising venous pressure.

Table III summarizes the experiments in this group, with the exception that the results on 2

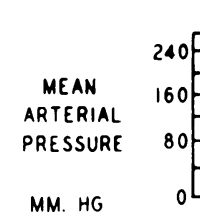

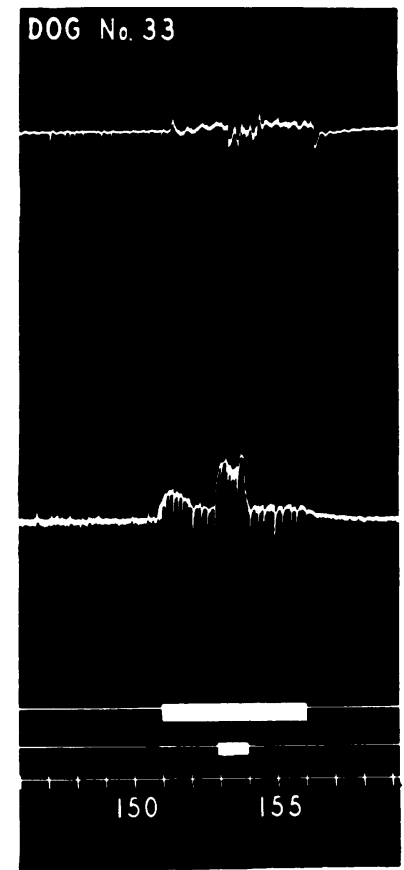
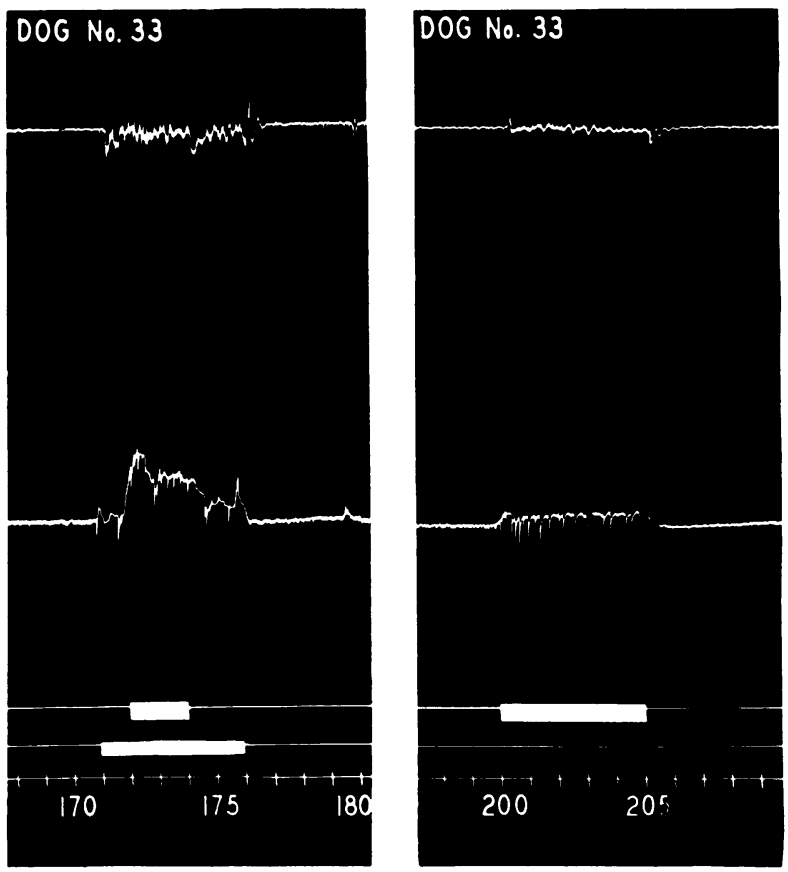

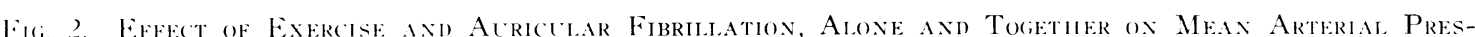
slre and Central. Venol's Presslre

Mean arterial presiure recorded by membrane manometer damped by partially closed stopcock. 
TABLE III

Effect of exercise on central venous pressure of dogs before and during induced auricular fibrillation

\begin{tabular}{|c|c|c|c|c|c|c|}
\hline \multirow[b]{2}{*}{$\begin{array}{l}\text { Method of stimulating } \\
\text { auricle }\end{array}$} & \multirow[b]{2}{*}{$\begin{array}{l}\text { Dog } \\
\text { no. }\end{array}$} & \multicolumn{4}{|c|}{ Change in central venous pressure } & \multirow[b]{2}{*}{ Comments } \\
\hline & & $\begin{array}{l}\text { By control } \\
\text { exercise } \\
\text { alone }\end{array}$ & $\begin{array}{l}\text { By auricular } \\
\text { fibrillation } \\
\text { alone }\end{array}$ & $\begin{array}{l}\text { By auricular } \\
\text { fibrillation } \\
\text { plus } \\
\text { exercise }\end{array}$ & $\begin{array}{l}\text { Increment due } \\
\text { to exercise } \\
\text { during } \\
\text { fibrillation }\end{array}$ & \\
\hline \multirow{3}{*}{$\begin{array}{l}\text { Electrodes sewed to } \\
\text { auricular wall; chest } \\
\text { closed af ter surgery }\end{array}$} & 31 & $\begin{array}{c}m m . H_{2} \mathrm{O} \\
-4\end{array}$ & $\begin{array}{c}m m . \mathrm{H}_{2} \mathrm{O} \\
+21\end{array}$ & $\begin{array}{c}m m . \mathrm{H}_{2} \mathrm{O} \\
+32\end{array}$ & $\begin{array}{c}m m . \mathrm{H}_{2} \mathrm{O} \\
+11\end{array}$ & . \\
\hline & 44 & -30 & $\begin{array}{l}+13 \\
+13\end{array}$ & $\begin{array}{l}+21 \\
+24\end{array}$ & $\begin{array}{l}+8 \\
+11\end{array}$ & $\begin{array}{l}\text { Continuous pleural aspi- } \\
\text { ration }\end{array}$ \\
\hline & 45 & -12 & $\begin{array}{l}+14 \\
+14\end{array}$ & $\begin{array}{l}+14 \\
+14\end{array}$ & $\begin{array}{l}0 \\
0\end{array}$ & \\
\hline \multirow{4}{*}{$\begin{array}{l}\text { Intra-auricular and } \\
\text { oesophageal elec- } \\
\text { trodes; no thoracic } \\
\text { surgery }\end{array}$} & 33 & +6 & $\begin{array}{l}+3 \\
+6 \\
+2\end{array}$ & $\begin{array}{l}+26 \\
+30 \\
+29\end{array}$ & $\begin{array}{l}+23 \\
+24 \\
+27\end{array}$ & \\
\hline & 38 & -4 & $\begin{array}{l}+16 \\
+16\end{array}$ & $\begin{array}{l}+20 \\
+16\end{array}$ & $\begin{array}{r}4 \\
0\end{array}$ & $\begin{array}{l}\text { Contractions poor; low } \\
\text { mean B.P. throughout }\end{array}$ \\
\hline & 40 & $\begin{array}{l}+19 \\
+4\end{array}$ & +25 & +43 & +18 & \\
\hline & 43 & 0 & $\begin{array}{l}+2 \\
+2\end{array}$ & $\begin{array}{l}+35 \\
+35\end{array}$ & $\begin{array}{l}+33 \\
+33\end{array}$ & \\
\hline
\end{tabular}

operated dogs have been omitted. One dog had an almost complete auriculoventricular block. Though auricular fibrillation could be produced at will, the ventricular rate never became rapid enough to impair cardiac "competence" and exercise produced the usual decrease of venous pressure. In the second $\operatorname{dog}$ a leak in the chest wound produced a pneumothorax which could not be controlled satisfactorily even by continuous aspiration.

As indicated to the left in Table. III, exercise prior to auricular fibrillation reduced venous pressure in 4 of 7 dogs by 4 to $30 \mathrm{~mm}$. water. In one dog exercise had no effect and in 2 others elevated venous pressure by 19,6 , and $4 \mathrm{~mm}$. water. The cause of these exceptions cannot be explained though they may conceivably have been due to differing anesthesia or to residual damage from several earlier, brief periods of auricular stimulation administered to verify the occurrence of auricular fibrillation. Auricular fibrillation alone elevated venous pressure by 2 to $25 \mathrm{~mm}$. water, whereas auricular fibrillation plus exercise produced elevations ranging from 16 to $43 \mathrm{~mm}$. water. Subtracting, in each experiment, the former from the latter indicates that in 5 of the 7 dogs the increment of venous pressure due to exercise alone ranged from +8 to $+33 \mathrm{~mm}$. water. In 2 experiments exercise did not raise venous pressure above the level produced by auricular fibrillation alone, probably because the maximum possible change had already been produced. Even in these 2 dogs exercise during fibrillation did not reduce venous pressure to the degree observed during control exercise.

Mean arterial blood pressure, measured by a damped membrane manometer, remained constant or rose during simple exercise as in the previous series. During fibrillation alone mean arterial pressure fluctuated widely, but on the average was only slightly below the control level. In combined exercise and auricular fibrillation, arterial pressure rose as much as $25 \mathrm{~mm}$. $\mathrm{Hg}$. or fell as much as $18 \mathrm{~mm}$. $\mathrm{Hg}$. without discernible relation to venous pressure. It is noteworthy that no large and consistent reduction of mean arterial pressure occurred during auricular fibrillation despite the trapping of blood in the venous portion of the circulatory system. This volume of blood may be considerable as will be indicated below and it must be concluded that arterial pressure is maintained under these conditions by compensatory reduction in the vascular volume and arterial blood flow of some areas, e.g., the kidneys and intestines. 
I comparison of the results in operated and unoperated animals reveals that exercise produced generally greater changes of renous pressure when prior surgery and blood loss were avoided and when auricular fibrillation had of itself not elevated venous pressure greatly. It seems clear that in the intact animal, as might be expected, the relations between venous pressure cardiac "competence" and the work demanded of the heart are not as simple as in the heart-lung preparation where the available supply of venous blood is independent of other factors. In the intact animal prior hemorrlage, prior venous distention and any dilatation of the peripheral vessels will reduce the return of venous blood to the heart and thereby lessen the peak venous pressure attained during exercise even in the presence of drastically reduced cardiac "competence." In these anesthetized dogs a rise of 30 or $40 \mathrm{~mm}$. water appears to be the greatest elevation compatible with normal blood volume, normal arterial pressure, and unobstructed blood flow. The effects of mechanical obstruction to cardiac filling will now be consiclered.

\section{Graded cardiac tamponade; effect on central zenous pressure aith and rithout exercise}

Graded cardiac tamponade was induced in 4 animals to observe the effects which muscular activity might exert on venous pressure already elevated by a physical obstruction to free flow.
With the pericardial cannula in place, the chest closed, and the zero of the pericardial manometer set at mid-thorax level, pericardial pressure could he elevated to any desired level before excrcise was starterl.

Resting venous pressure and the effects of control exercise having been recorded (a) measured volumes of fluid were injected into the pericardial sac, resting venous pressure readlings recorded. and the animal then exercised; or (b) sufficient fluid was allowed to enter the pericardium to raise venous and pericardial pressures to an arbitrary level and then exercise was induced with the reservoir arranged to maintain this pressure throughout. Between these procedures fluicl was withdrawn from the pericardial sac to bring pericardial pressure to its resting level before another (o)servation was undertaken.

Pressure in the superior vena cava in resting animals followed changes of pericardial pressure quite closely with differences less than $10 \mathrm{~mm}$. in 19 out of 31 trials and of 10 to 30 mlnt. in 11 trials. In the one remaining instance acciclental aspiration of air into the pericardium during exercise was responsible for an unustally wide discrepancy.

Exercise during cardiac tamponade, as shown in Figure 3, was generally associated with a reduction of venous pressure similar in magnitude to that observed in the same animal before pericarclial pressure was elevated. Table IV gives a complete summary showing that while exercise

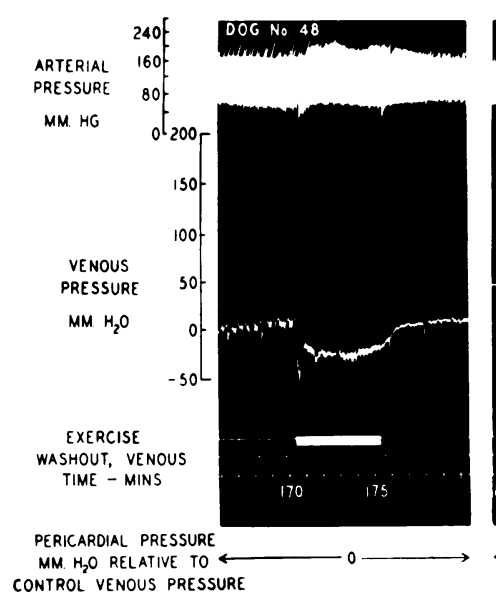

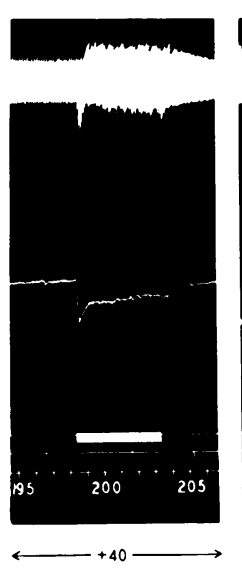

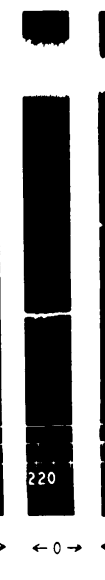

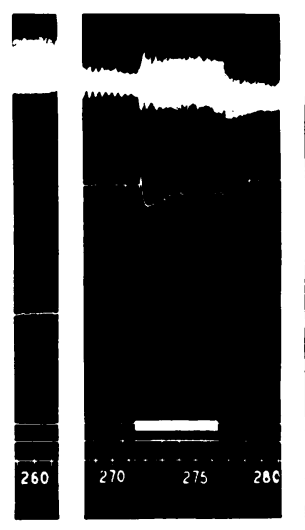

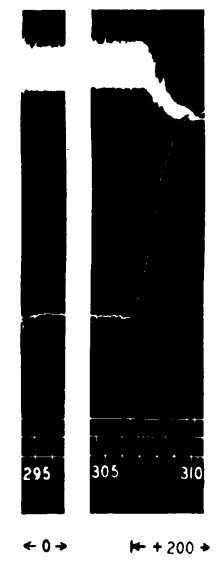

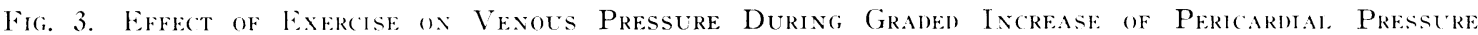
(Cardiac Tamponade)

Arterial pressure recorded by membrane manometer. 
usually reduced venous pressure under these conditions the effects were not entirely consistent. Differences in response could not be correlated with heart rates, as shown in the last column of Table IV. However, it seems significant that in the three observations in which venous pressure was elevated during exercise this effect occurred under circumstances such that prior myocardial damage from partial asphyxia may well have been present, i.e. twice in one animal (Dog 49) which had suffered from hemorrhage and the effects of prolonged arterial hypotension (40 to $50 \mathrm{~mm}$. $\mathrm{Hg}$.), and once in a second observation (Dog 47), the first test of this animal having given the more usual result. In any case, the state of all these dogs was precarious $(a)$ because arterial pressure, and therefore coronary blood pressure, were lowered even by mild tamponade and $(b)$ because elevating pericardial pressure to $170 \mathrm{~mm}$. water or more (see Figure 3) produced an abrupt fall of arterial pressure and terminal rise of venous pressure during asphyxia and ventricular fibrillation.

The mechanism by which muscular activity lowered venous pressure during cardiac tampon-

TABLE IV

Effect of graded cardiac tamponade and exercise, singly and together, on central venous pressure and mean arterial pressure

\begin{tabular}{|c|c|c|c|c|c|c|c|}
\hline \multirow{3}{*}{$\begin{array}{l}\text { Dog } \\
\text { no. }\end{array}$} & \multirow{3}{*}{$\begin{array}{c}\text { Change } \\
\text { of } \\
\text { venous } \\
\text { pres- } \\
\text { sure } \\
\text { during } \\
\text { exer- } \\
\text { cise } \\
\text { (con- } \\
\text { trol) }\end{array}$} & \multicolumn{6}{|c|}{ During graded tamponade } \\
\hline & & \multirow{2}{*}{$\begin{array}{c}\text { Peri- } \\
\text { cardial } \\
\text { pres- } \\
\text { sure }\end{array}$} & \multirow{2}{*}{$\begin{array}{l}\text { Venous } \\
\text { pres- } \\
\text { sure }\end{array}$} & \multicolumn{2}{|c|}{$\begin{array}{c}\text { Change of } \\
\text { arterial pressure }\end{array}$} & \multirow{2}{*}{\begin{tabular}{|c|} 
Change \\
of \\
venous \\
pres- \\
sure; \\
tam- \\
ponade \\
plus \\
exer- \\
cise
\end{tabular}} & \multirow{2}{*}{$\begin{array}{c}\text { Heart } \\
\text { rate } \\
\text { during } \\
\text { tam- } \\
\text { ponade } \\
\text { plus } \\
\text { exer- } \\
\text { cise }\end{array}$} \\
\hline & & & & $\begin{array}{c}\text { Tam- } \\
\text { ponade } \\
\text { only }\end{array}$ & $\begin{array}{c}\text { Tam- } \\
\text { ponade } \\
\text { plus } \\
\text { exer- } \\
\text { cise }\end{array}$ & & \\
\hline 46 & $\begin{array}{c}\underset{H_{2} \mathrm{O}}{ } . \\
-25\end{array}$ & $\begin{array}{r}\underset{\mathrm{H}}{\mathrm{H}} \mathrm{O} \\
85 \\
45\end{array}$ & $\begin{array}{r}\underset{\mathrm{H}_{2} \mathrm{O}}{ } . \\
88 \\
42\end{array}$ & $\begin{array}{c}m m . \\
H g \\
-9 \\
-6\end{array}$ & $\begin{array}{l}\underset{H g}{m g} \\
+6\end{array}$ & $\begin{array}{l}\mathrm{mm}_{2} \mathrm{O} \\
-13\end{array}$ & $\begin{array}{c}\text { beats } \\
\text { per min. }\end{array}$ \\
\hline 47 & -13 & $\begin{array}{l}40 \\
95\end{array}$ & $\begin{array}{r}38 \\
100\end{array}$ & $\begin{array}{r}0 \\
-15\end{array}$ & $\begin{array}{l}+5 \\
-16\end{array}$ & $\begin{array}{l}-15 \\
+13\end{array}$ & $\begin{array}{l}228 \\
264\end{array}$ \\
\hline 48 & -31 & $\begin{array}{r}40 \\
100 \\
150\end{array}$ & $\begin{array}{r}48 \\
100 \\
141\end{array}$ & $\begin{array}{l}-4 \\
-15 \\
-22\end{array}$ & $\begin{array}{l}-3 \\
-12 \\
-18\end{array}$ & $\begin{array}{l}-17 \\
-15 \\
-12\end{array}$ & $\begin{array}{l}160 \\
160 \\
264\end{array}$ \\
\hline 49 & -6 & $\begin{array}{l}50 \\
70\end{array}$ & $\begin{array}{l}57 \\
61\end{array}$ & $\begin{array}{l}-59 \\
-32\end{array}$ & $\begin{array}{l}-6 \\
-8\end{array}$ & $\begin{array}{l}+7^{*} \\
+13\end{array}$ & $\stackrel{240}{t}$ \\
\hline
\end{tabular}

* Transient rise. This dog lost a large volume of blood during operation and had low mean blood pressure with tachycardia thereafter.

$\dagger$ Died in third minute of second bout of exercise. ade is not simple but can probably be explained by the effects of widely fluctuating intrathoracic pressure during the hyperpnea of exercise. In some experiments mean pericardial pressure was kept constant during exercise by permitting fluid to flow freely into, or out of, the pericardial sac from a reservoir bottle set at the desired level. At rest, with normal respiration, the level of fluid in the reservoir remained constant and respiratory fluctuations in pericardial pressure were slight. With the beginning of exercise and of deeper, more rapid respiration, between 5 and $45 \mathrm{ml}$. of fluid entered the pericardial sac, while mean intrapericardial pressure remained constant, indicating clearly an increase in the volume of the already distended pericardial sac. This, coupled with the greatly magnified respiratory variations of pericardial pressure (about the mean which remained constant) indicates that the wide fluctuations of intrathoracic pressure, and particularly its intermittent lowering during deep inspirations, reduced the average effectiveness of the pericardial barrier to venous return and auricular filling. In effect, during exercise the "pumping" action of deep and frequent breathing assisted the entrance of blood into the heart whereas at rest, during normal breathing, the same mean pericardial pressure exerted a more sustained and effective resistance to venous blood flow.

If this explanation is valid, it may be surmised further that once past the mechanical barrier, blood entered the relatively normal heart and was expelled efficiently. Under these conditions exercise could not produce any disparity between the "load of venous return" and the "competence" of the heart, the latter in this instance being per se still normal. Hence in this situation, the effect of exercise on venous pressure appears to be more closely related to the state of cardiac "competence" than to mechanical disturbances outside the heart.

The lowering of central venous pressure observed in the control exercise of normal animals must also be due in part to the well known "pumping" action of the increased respiration produced by muscular activity. With normal cardiac "competence" such intermittent aspiration should logically lead to a reduction of central venous pressure as long as the right ventricle can effectively handle any volume which the peripheral 
veins can supply. The same or greater aspiration which occurred in animals with damaged hearts did not. however, reduce central venous pressure because the right ventricle, stressed beyond its "competence" could not evacuate the large veins effectively. Lnder these conditions venous pressure rose despite greater aspiration because the function of the right ventricle was the limiting factor.

5. Acute increase of blood ablume: effects on a'cnous pressure during rest and cerercise

Increased blood volume is unquestionably an important, though variahle, associated feature of chronic congestive failure in man. Rapid infusions have also produced certain signs of congestive failure in normal (logs (1t). If it is true that the high resting venous pressure in cardiac failure is clue to this increased blood volume por se (2, 3), it should be possible. by suitably large transfusions of blood into normal dogs (a) to raise venous pressure in resting animals for long periods of time, and (b) to produce a definite sustained rise of venous pressure during exercise,-a reaction which, from evidence given above, occurs characteristically when cardiac function is interfered with. Neither was olsserved. however, after transfusions into normal dogs of enough whole blood to increase the calculated blood volume by 50 per cent and in a second series by 100 per cent or more.

(a) Transfusion of blood iqual to 5 () per cont of calculated blood volume. Figure $t$ shows the record of a representative experiment in this group but the results of this and two similar observations will be described together. Control exercise for 5 minutes reduced venous pressure in the usual fashion in each instance, i.c. by $-34 .-17$ and $-22 \mathrm{~mm}$. water. Transfusions of 880.875 , and $650 \mathrm{ml}$. of blood were then given, preceded in each instance by $50 \mathrm{ml}$. Ringer's solution; for lody weights of $17.8,17.5$, and $13 \mathrm{kgm}$. this increased the calculated blood volume by slightly more than 50 per cent. The rates of injection averaged 59, 95, and $95 \mathrm{ml}$. per minute but, as Figure 4 shows, were not quite uniform because 5 seconds of each 30 were required to refill the 50 inl. syringe.

Venous pressure rose rapilly after the first $100 \mathrm{ml}$. of blood entered and. by the end of the transfusion, reached peak values exceeding the previous resting venous pressure by 69. 140, and $227 \mathrm{~mm}$. water. As soon as the transfusion ceased venous pressure began to fall rapidly and reached the pre-transfusion level in $7.5 \quad 19$ and 19.5 minutes.

Standard exercise was induced for 5 minutes (a) beginning within 2 to $1+$ minutes after the end of transfusion while venous pressures were still alove normal and (b) 27 to 39 minutes after the end of transfusion when venous pressures were once more in the normal range. Exercise induced while venous pressure was still high, i.e. 47. 51 and $80 \mathrm{~mm}$. above normal, was associated with continued clecline of venous pressure by 36 , 4). and $68 \mathrm{mmm}$. water. It had very little effect on the general contour of the descending limb of the curve except for a very transient rise resembling that seen in some normal animals and apparently
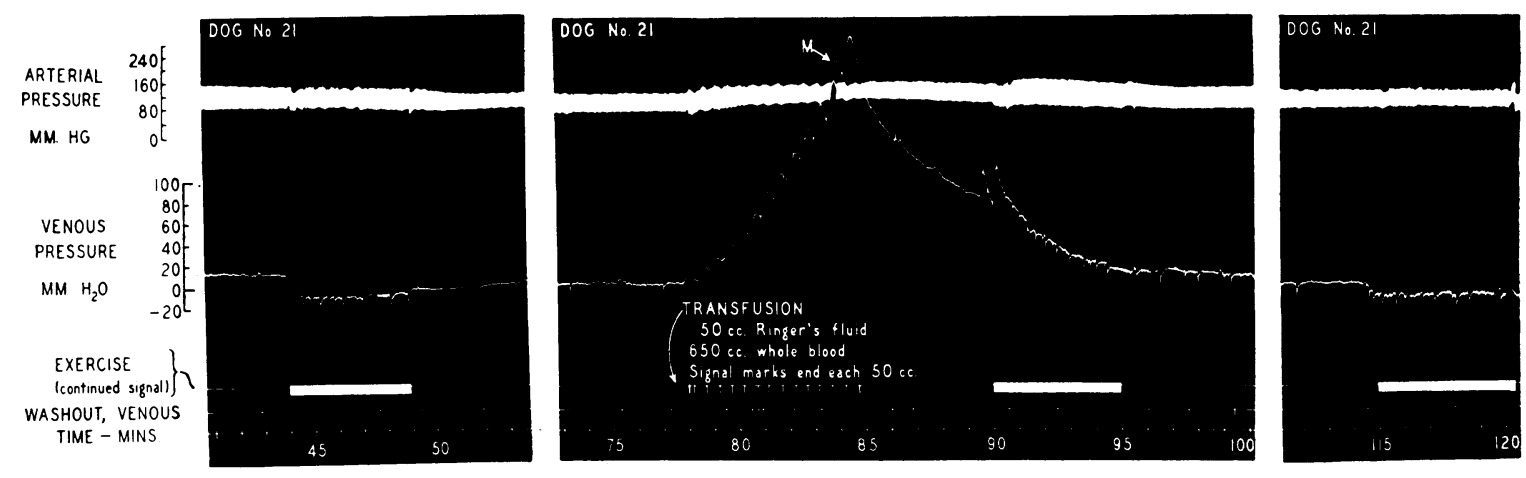

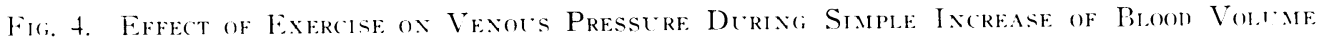

Arterial pressure recorded by membrane manometer. At " $\mathrm{M}$ " venous pressure recorder moved slightly to left to escape writing point of membrane manometer. 
due to sudden compression of veins by the initial contractions of the adjacent muscles, with consequent temporary and vigorous propulsion of blood toward the heart. Even this interruption failed to affect appreciably the continued decline of venous pressure which reached essentially normal values during, and despite, exercise. Renewed exercise, after a rest period of 20 minutes or more, was also associated with a lowering of venous pressure, amounting to $-7,-8$, and $-15 \mathrm{~mm}$. water.

Hence, in the dog at least, simple plethora equivalent to that found in chronic congestive failure of man did not produce a persisting increase in resting venous pressure nor did it lead, with exercise, to the rise of venous pressure which in previous experiments was associated with known cardiac damage.

It seemed possible that rapid filtration of fluid might have reduced the plethora so rapidly that the increase in blood volume and venous pressure were not great enough during exercise to produce a sufficient circulatory handicap. Hence a converse experiment was arranged so that venous pressure might be kept constantly high before and during exercise by whatever transfusion or infusion rate was required.

(b) Maintenance of a uniformly elevated venous pressure; volume of blood or Ringer's solution required and the effect of exercise. As might be suspected from the preceding section enormous volumes and very rapid infusion rates were necessary to keep venous pressure consistently above resting venous pressure. With the largest possible cannula in the left jugular vein, the calibrated Mariotte flask was set at the desired level above the previously established resting venous pressure. The transfusion or infusion rate per minute was recorded on the smoked drum by marking the times at which the level of fluid in the flask passed $100 \mathrm{ml}$. calibrations on the wall of the flask while venous pressure was kept relatively constant at the desired level throughout. Whole blood or Ringer's fluid entered the jugular vein very rapidly at first but, as venous pressure ascended quickly to the desired level within 2 to 5 minutes, the rate of flow became slightly slower and relatively constant.

Wholly unphysiological amounts of blood or of Ringer's solution had to be infused in order to maintain venous pressure at levels approaching those seen in chronic congestive failure of man. In 3 dogs, weighing between 13.3 and $16 \mathrm{kgm}$. each, the transfusion of between 2.4 and 2.7 liters of blood was required to hold central venous pressure relatively constant at set levels between 50 and $200 \mathrm{~mm}$. water above the normal resting venous pressure for a total of 50 to 80 minutes. During this period, blood entered the vascular system at rates between 0.9 and $3.6 \mathrm{ml}$. per $\mathrm{kgm}$. per minute. When Ringer's fluid was used to maintain similar elevations of venous pressure for similar periods in 3 dogs weighing between 12 and $14 \mathrm{kgm}$., the total volume necessary ranged from 3.6 to 4.5 liters and the infusion rates from 4.5 to $6.1 \mathrm{ml}$. per $\mathrm{kgm}$. per minute. The total volume of injected fluid ranged from 161 to $222 \mathrm{ml}$. per $\mathrm{kgm}$. for blood and from 285 to $320 \mathrm{ml}$. per $\mathrm{kgm}$. for Ringer's fluid.

Stopping the infusion was followed by an initially precipitous, and then slower, fall of venous pressure to the resting level within 30 minutes in 3 dogs. In the remaining 3 dogs ( 1 with blood, 2 with Ringer's fluid) venous pressure also fell initially but remained 178,30 , and $47 \mathrm{~mm}$. water above the respective resting levels for 70 minutes or more.

As in the previous series, exercise induced while venous pressure was still elevated or after it had returned to the resting level, invariably lowered the venous pressure. Even in the most extreme case in which the transfusion of $2450 \mathrm{ml}$. of blood produced a fairly persistent rise of venous pressure to $178 \mathrm{~mm}$. above normal, 2 bouts of exercise still reduced venous pressure. Again it appeared that the rise of venous pressure with exercise is more closely related to interference with cardiac function than to circulatory changes external to the heart. Simple hypervolemia did not cause exercise to elevate venous pressure, though coronary ligation and auricular fibrillation did so even when blood volume remained normal.

\section{The change in vascular volume which corre- sponds to the asphyxial (or maximal) rise of venous pressure}

The vascular system with its contained blood can be regarded as a filled and unequally elastic closed reservoir in which, during life, pressure and volume are balanced at different levels spati- 
ally (i.e. in arteries, capillaries and veins) as well as in time. In the later stages of asphyxia, as the heart beat grows feebler and as agonal vasoconstriction develops, spatial differences disappear ; arterial pressure falls, and venous pressure rises. This agonal rise of venous pressure results from $(a)$ redistribution of an unknown volume of blood as the arteries empty and the veins fill, and $(b)$ an agonal and intense constriction of arteries, capillaries and veins.

The values of $(a)$ and $(b)$ are directly related to each other, however, because the circulatory system is closed and total blood volume will remain constant over a period of a few minutes. Obviously a certain "dead space" must always exist in the vascular system since the rather rigid aorta and the large arteries will contain some blood even when maximally constricted and at low pressure, owing to reduced cardiac output. The same holds for the blood reservoirs and the large veins whose feeble musculature cannot evacuate them completely even at resting venous pressure. Much more complete emptying can be expected in the case of the arterioles, capillaries, and venules. Measuring the volume of blood expressed during constriction of these vessels will indicate approximately, in terms of milliliters, the power of vasoconstriction to compensate for that "trapping of blood" in the venous system which a rise of central venous pressure may produce.

This maximum possible decrease in vascular volume was determined in 3 heparinized dogs. During the usual recording of venous and arterial pressures the trachea was clamped but instead of allowing venous pressure to rise during asphyxia, a calibrated reservoir partially filled with Ringer's solution was connected to both external jugular veins and adjusted so that the level of the contained blood equalled exactly the resting venous pressure. The largest possible cannulae and connecting tubes were used to permit as rapid an outpouring of blood as possible when developing asphyxia tended to elevate venous pressure. As blood entered the reservoir its position relative to the animal was lowered to keep the fluid level always equal to the previously determined resting venous pressure. The volume expelled by the whole vascular tree was recorded on the smoked drum by $50 \mathrm{ml}$. increments. In effect, the asphyxial rise in venous pressure was translated into a curve representing decrease in vascular volume. As might be expected, blood left the veins rapidly at first then more slowly. The shape of the curve relating the expelled volume to time was roughly similar to the curve of venous pressure in asphyxia.

In 3 dogs, weighing 15.5 to $15.6 \mathrm{kgm}$. the results were quite constant, viz. a total volume of 325 to $360 \mathrm{ml}$. was expelled during asphyxia at normal resting venous pressure. This was equivalent to 21.0, 22.2, and $22.4 \mathrm{cc}$. per $\mathrm{kgm}$. Assuming a blood volume of 8 per cent of body weight this would correspond to a maximal decrease of vascular volume of 26 to 28 per cent of average normal blood volume. The corresponding figure for a man weighing $75 \mathrm{kgm}$. would be approximately $1600 \mathrm{ml}$.

\section{DISCUSSION}

Resting venous pressure obviously has limited value as an indicator of cardiac function in the intact animal. The burden placed upon the heart by resting venous return is so small that only marked, and near-lethal, reductions of cardiac "competence" will produce a significant rise of resting venous pressure. This limitation has been recognized clinically for a long time as shown by published descriptions of numerous test procedures designed to add precision to measurements of cardiac function by measuring venous pressure while increasing temporarily the volume of blood returned to the heart, e.g. by muscular activity (6 to 10), pressure on the upper abdomen (15), intravenous infusions (16 to 18 ), and passive elevation of the lower extremities $(16,19)$.

On the other hand, venous pressure measured during activity is more helpful in explaining the pathogenesis of the edema and plethora of congestive failure. In the observations on dogs now described, exercise elevated venous pressure very frequently after ligation of coronary arteries and during auricular fibrillation but very infrequently during cardiac tamponade and never when blood volume was increased moderately or markedly. The development of "back-pressure," or rise of venous pressure during stress, was more directly related to interference with cardiac function than to artificially induced acute plethora or to mechanically produced elevations of venous pressure. This "back-pressure," as measured in the intact 
animal, resembled qualitatively that seen in the heart-lung preparation by Starling (1) and Krayer (4) but was not as striking quantitatively because of the conditions imposed by a limited blood volume and by a closed, but elastic, vascular system.

It may be objected that the rise of venous pressure seen with exercise was due merely to general vasoconstriction or to constriction of veins and not to "back-pressure" of cardiac origin. Such a view leaves unexplained, however, the lowering of venous pressure produced by exercise $(a)$ during severe cardiac tamponade and $(b)$ during periods of mild or severe hypervolemia.

The first effect of any rise of venous pressure due to overtaxing of the heart's "competence" will be a redistribution of blood toward the veins, venules, and venous capillaries $(1,2,20)$. The volume which can be thus redistributed without a fall of arterial pressure is vanishingly small in a circulation schema (20) but much larger in the intact animal because the vascular system, unlike the schema, can $(a)$ constrict generally or $(b)$ constrict selectively so that whole sections of the body (e.g. skin, intestines and kidneys) both receive, and also contain, less blood than normal. The volume of blood flowing from the veins at constant venous pressure during asphyxia suggests that this volume may be quite large, approaching 2.0 to 2.2 per cent of body weight. These figures are admittedly approximate but help explain the apparent anomaly that venous pressure during exercise can be elevated while arterial pressure is still maintained at its normal level.

This volume is changed, however, by the loss of plasma volume through prior filtration or by gain of volume from infusions. In 2 dogs after combined auricular fibrillation and prolonged exercise the change of vascular volume during asphyxia was reduced from the normal 2.0 per cent of body weight to 0.9 and 1.1 per cent of body weight. In a third dog, after infusion of 3600 ml. of Ringer's fluid and similar exercise, asphyxia reduced vascular volume, venous pressure being kept constant, by $4.0 \mathrm{ml}$. per $\mathrm{kgm}$., or double the normal amount.

It may be recalled that in dogs hemorrhage amounting to between 2 and 3.7 per cent of body weight can be sustained without change in arterial blood pressure, though the heart's diastolic volume is reduced and the vessels of the skin show compensatory constriction $(21,22)$. The ability of the vascular system to compensate for loss, or temporary displacement, of blood is considerable. In the human being certainly $700 \mathrm{ml}$, and possibly $1000 \mathrm{ml}$, of blood can be trapped in the venous system before arterial pressure need fall but this can only be accomplished by a major sacrifice of blood flow to some areas of the body, particularly the skin and the splanchnic region including the kidneys. A similar reaction is seen during quiet standing in which sequestration of blood in dependent veins, and loss of plasma volume by filtration, are accompanied by cessation of absorption of fluid by the gastrointestinal tract and by reduced excretion of water by the kidneys (23).

The second consequence of "back-pressure" is an enhanced filtration everywhere in the capillary bed. Plethysmographic observations by Landis and Gibbon (24) have shown that in man venous pressures above $100 \mathrm{~mm}$. water cause fluid to accumulate in the tissue spaces at the rate of $0.0033 \mathrm{ml}$. per $100 \mathrm{ml}$. of tissue per min. per $\mathrm{cm}$. rise in venous pressure. These measurements apply to the capillaries in the forearm which are relatively impermeable to protein. A rise in central venous pressure will, however, affect not only these capillaries but also the much more permeable networks (1) of the liver where fluid movement will be several times greater, for a given increment in venous pressure. Translated to the patient with cardiac disease, it appears that if exercise raises venous pressure by $100 \mathrm{~mm}$. water above the previous resting level, fluid can be filtered from the blood stream at a rate of at least 25 to $30 \mathrm{ml}$. per minute-or 250 to $300 \mathrm{ml}$. in the relatively short period of 10 minutes.

In dogs these figures were, in fact, exceeded considerably when venous pressure was kept consistently above resting level by whatever infusion rate might be required. To maintain venous pressure approximately $100 \mathrm{~mm}$. above the resting level with blood required continuous transfusion at rates up to $3.6 \mathrm{ml}$. per $\mathrm{kgm}$. body weight per minute, owing to distention of the vascular bed and filtration. To sustain the same venous pressures by infusing Ringer's solution required from 4.5 to $6.1 \mathrm{ml}$. per $\mathrm{kgm}$. per minute. Since the vascular system was equally distended the differ- 
ence between these rates indicates approximately the rate at which Ringer's fluid was filtered from the whole capillary bed at a venous pressure 100 $\mathrm{mm}$. above resting level, viz. for the dog 0.9 to $2.5 \mathrm{ml}$. per $\mathrm{kgm}$. per minute. Translated to a man weighing $75 \mathrm{kgm}$., this would amount to between 67 and $187 \mathrm{ml}$. per minute, or to between 670 and $1870 \mathrm{ml}$. per 10 minutes. These figures are admittedly approximate, and for several reasons (e.g. differences of blood reservoirs and of musculature and reactions of the hepatic veins) not to be applied to man in a quantitative sense, but they illustrate the direction and order of magnitude of the secondary circulatory effects produced by any excessive rise of venous pressure in the active cardiac patient. They suggest that exercise may produce acute changes in available or "effective" blood volume which are large enough to call into play emergency vasoconstrictor mechanisms.

The diurnal increase, and nocturnal decrease, of plasma protein concentration observed in cardiac patients with nocturnal dyspnea (25) indicate shifts of fluid having this direction and general order of magnitude. On the other hand, reports dealing with the effects of exercise on circulating blood volume in man, normal and diseased, are quite completely at variance with each other (26). It seems likely that the methods used so far have been inadequate for the purpose.

Finally, it must be recalled that neither plethora nor diminished power of the kidney to excrete water and sodium are uniquely restricted to congestive failure, nor are they by any means found only in conjunction with an elevated venous pressure. Even in cardiac patients the relations between failure, plethora, resting venous pressure and diuresis are not consistent from case to case (27, 28). In polycythemia vera circulatory pressures and dynamics are quite normal despite increased blood volume $(28,29)$ until cardiac failure appears as an incidental development. Conspicuously reduced renal excretion of water and sodium is a prominent secondary feature of the nephrotic syndrome (30) and also of the reaction of normal subjects to quiet standing (23) without plethora or rise in venous pressure in either case. In fact, blood volume and venous pressure are lower than normal in these conditions.
The routine study of cardiac patients has placed undue emphasis on resting venous pressure. Hence the relation between cardiac "competence," venous pressure and plethora are difficult, or even impossible, to understand until the considerable changes produced by prior muscular activity are also included. When this is done the reactions of the heart-lung preparation and of the intact animal become more similar and the characteristic responses of the closed circulatory sysstem more evident. As a working hypothesis, for future testing in patients with cardiac disease, the following sequence appears to integrate the available information from the failing heart in the heart-lung preparation, dogs with cardiac damage and human beings with reduced cardiac "competence."

1. Intermittent increase (absolute or relative) of venous pressure during muscular activity. This is not a sustained abnormality at first but is a brief occurrence repeated many times daily during periods of activity. It tends to become more frequent and sustained as the instructions concerning activity are neglected, and as cardiac "competence" diminishes. It depends primparily upon the inability of a heart with reduced "competence" to cope with the increased venous return of muscular activity. Resting venous pressure will fail entirely therefore to indicate the earlier stages of reduced "competence."

2. Temporary sequestration of blood, during muscular activity, in the venous system accompanied by excessive filtration of fluid. Both will be more marked, more immediate and more persistent in poorly supported tissues, e.g. liver and intestines and in dependent tissues. The production, by effort, of acute right upper quadrant pain in right ventricular failure and the occurrence in patients of hepatic enlargement with normal resting venous pressure (31) thus become understandable.

3. Intermittent reduction, during activity, of circulating blood volume. This comprises reduction of "effective" circulating blood volume by trapping of blood in the great veins and also by reduction of absolute plasma volume owing to excessive filtration. The grade of activity which calls forth these reactions will vary widely from patient to patient depending upon the grade of reduced cardiac "competence" actually present. 
4. Compensatory vasoconstriction. From what is known to occur in other conditions it may be expected that reduction of "effective," and also actual, blood volume will lead to (a) compensatory vascoconstriction, (b) reduced renal excretion of sodium and water and (c) over-production of erythrocytes and plasma proteins. The reactions resemble in mechanism and cumulative effect those produced by hemorrhage or quiet standing, except that with these stresses compensation is a single occurrence, whereas in the cardiac patient the sequence may be repeated in lesser degree many times daily with each injudicious exertion. The bone marrow of patients with congestive failure is hyperactive (32), and cutaneous reactive hyperemia is said to be delayed (33) but both return to normal as compensation is regained under treatment. Equally significant is the reduced renal excretion of water found not only in congestive failure, but also in the normal subject during quiet standing (23). The division between "backward failure" and "forward failure" (34) becomes somewhat less rigid because the former may, through changes in effective blood volume, lead during activity to the latter.

5. Secondary plethora or hypervolemia. The increase of blood volume which now appears may perhaps be advantageous at first to the ambulatory, active patient with reduced cardiac "competence." It may permit him to indulge in greater activity than would otherwise be possible before temporary and repeated "back-pressure" reduces effective blood volume to dangerously low levels.

But this same plethora, whether or not it is advantageous during activity, becomes disadvantageous or even a real danger when rest in the recumbent position, intermittently at night or continuously in the early days of treatment, leads to $(a)$ relief of venous distention and $(b)$ reabsorption of tissue fluid. At this stage venesection or prompt diuresis is required because they alone can expedite adjustment to a new scale of reduced activity. That these changes of blood volume with abrupt change in activity and posture can be dangerously large is indicated not only by the observations on dogs dessribed above, but also by the diurnal changes in the concentration of plasma proteins in patients subject to nocturnal dyspnea (25), and by the clinically observed deleterious effects of suddenly insisting upon complete bed rest (35).

6. High resting venous pressure of chronic congestive failure. The final result, a high venous pressure at rest, cannot be due to plethora alone because with normal cardiac "competence" plethora equal to that in congestive failure does not affect venous pressure for more than a few minutes. Trebling the blood volume by massive transfusion produced a persistent rise of venous pressure in 1 of 3 dogs but even this severe plethora did not cause exercise to elevate venous pressure in the manner characteristic of reduced cardiac "competence" when blood volume was normal. It appears that the fundamental fault in congestive failure is a reduced cardiac "competence" subjected by bed rest to the additional burden of plethora. During activity this plethora seems to be a compensatory, and possibly advantageous, result of repeated "back-pressure" and vasoconstriction during activity. At bed rest, however, the redistribution of blood volume and the reabsorption of edema fluid makes this plethora not only more pronounced but through elevated venous pressure makes dyspnea more marked (34) and pulmonary edema more likely (25).

From this combined pathogenesis it would be expected that an initially high venous pressure might be lowered during treatment by one or more of several factors, viz.: (a) reduction of muscular activity by strict bed rest, $(b)$ improvement of cardiac "competence" by medication, and $(c)$ reduction of blood volume and edema by venesection or diuretic agents. If venous pressure continues to rise, or does not fall, prognosis is poor. Even when venous pressure becomes normal at rest there is no assurance that it, and blood volume, will remain normal when activity is resumed. For full information on this point it would be necessary to measure venous pressure during carefully graded muscular activity.

Hence, extending the back-pressure" hypothesis derived from the heart-lung preparation to the intact animal is possible and logical, providing allowance is made for the limitations of the closed vascular system and for the advantages of its compensatory vasoconstriction. This sequence and its corollaries seem to agree with laboratory observations and clinical experience more satisfactorily 
than do hypotheses which consider plethora to be the primary factor in the clinical syndrome of congestive failure.

\section{SUM MARY}

To compare the effects of reduced cardiac "competence" and increased blood volume on venous pressure, the relation of central venous pressure to exercise, cardiac damage and increased blood volume was determined in dogs anesthetized with a mixture of morphine, chloralose, and urethane.

In normal dogs the exercise and hyperpnea produced by stimulating the muscles of all four extrensities once per second reduced venous pressure conspicuously.

Ligation of the right coronary artery, the circumflex artery, or the ramus descendens alone or together did not elevate resting venous pressure (one exception, Figure 1F) but in over half the animals that escaped ventricular fibrillation, exercise produced a slight but definite rise of venous pressure.

Exercising dogs with induced auricular fibrillation also elevated venous pressure slightly but definitely.

On the contrary, increased pericardial pressure (cardiac tamponade) elevated resting venous pressure, but exercise lowered venous pressure as in normal animals, unless prior myocardial ischemia had reduced cardiac "competence."

Simple plethora, induced by rapidly transfusing whole blood ( 5 per cent of body weight) into dogs with intact hearts, produced marked but transient elevations of venous pressure. Conversely, it was found that in order to maintain venous pressure at levels between 50 and $200 \mathrm{~mm}$. water above resting levels, blood had to be infused at rates of 0.9 to $3.6 \mathrm{ml}$. per $\mathrm{kgm}$. per minute. Exercise begun while the venous pressure was elevated was accompanied by a fall of venous pressure in every case, just as in animals with normal blood volume. It can be concluded that in these dogs elevation of venous pressure accompanied exercise when cardiac "competence" was reduced but not when blood volume was increased.

"Back-pressure" occurring during exercise did not necessarily reduce arterial pressure even though considerable blood must have been trapped in the large veins. To determine the volume of blood that could be thus transferred, the volume of blood issuing from the great veins was measured during asphyxia, while venous pressure was kept constant. Agonal vasoconstriction reduced vascular volume by 2.0 to 2.2 per cent of body weight under these conditions.

Taking into account these figures and those on rates of filtration of fluid at high venous pressures, it is suggested that the plethora of chronic congestive failure is a compensatory reaction to many episodes of reduced "effective" blood volume occurring in the course of repeated transient elevations of venous pressure during muscular activity whenever venous return exceeds cardiac "competence." As Starling originally suggested, the transfer of blood to the venous side of the circulation lowers the "effective" blood volume and together with loss of plasma volume by filtration can induce reflex arteriolar constriction similar to that seen in hemorrhage and quiet standing. Moreover, from this reduction of "effective," and also actual, blood volume it is logical to expect in cardiac failure, as in hemorrhage, a retention of sodium and water, as well as the overproduction of erythrocytes and plasma proteins which are characteristic features of the clinical syndrome "chronic congestive heart failure."

It is further suggested that this plethora may conceivably be advantageous to the active cardiac patient because it permits compensating for repeated depletion of "effective" circulating blood volume to critical levels during any exertion great enough to tax the heart's "competence." In agreement with clinical experience this same plethora should logically be disadvantageous to the patient at rest and particularly when recumbent.

\section{BIBLIOGRAPHY}

1. Starling, E. H., The Fluids of the Body. W. T. Keener and Co., Chicago, 1909.

2. Starr, I., Jeffers, W. A,, and Meade, R. H., The absence of conspicuous increments of venous pressure after severe damage to the right ventricle of the dog, with a discussion of the relation between clinical congestive failure and heart disease. Am. Heart J., 1943, 26, 291.

3. Warren, J. V., and Stead, E. A., Jr., Fluid dynamics in chronic congestive heart failure. An interpretation of the mechanisms producing edema, increased 
plasma volume and elevated venous pressure in certain patients with prolonged congestive failure. Arch. Int. Med., 1944, 73, 138.

4. Krayer, O., Versuche am insuffizienten Herzen. Arch. f. exper. Path. u. Pharmakol., 1931, 162, 1.

5. Richards, D. W., Jr., Cournand, A., Darling, R. C., Gillespie, W. H., and Baldwin, E. de F., Pressure of the blood in the right auricle, in animals and in man, under normal conditions and in right heart failure. Am. J. Physiol., 1942, 136, 115.

6. Schott, E., Die Erhöhung des Druckes im venösen System bei Anstrengung als Mass für die Funktionstïchtigkeit des menschlichen Herzens. Deutsches Arch. f. klin. Med., 1912, 108, 537.

7. Bedford, D. E., and Wright, S., The venous pressure in normal individuals. Lancet, 1924, 2, 106.

8. Tetelbaum, A. G., Umanski, S. I., and Krynski, M. I., Über den Einfluss der körperlichen Belastung auf den Venendruck bei Gesunden und bei dekompensierten Herzkranken. Wien. Arch. f. inn. Med., 1935, 28, 121.

9. Nieuwenhuizen, C. L. C. v., Der venöse Blutdruck nach Arbeitsleistung, eine Funktionsprüfung der Zirkulation. Acta med. Scandinav., 1940, 103, 171.

10. Szekely, P., Venous pressure responses to exercise; preliminary report. Am. Heart J., 1941, 22, 360.

11. Fauteux, M., Coronary disease; experimental and clinical study. To be published.

12. Stewart, H. J., Crawford, J. H., and Hastings, A. B., The effect of tachycardia on the blood flow in dogs. I. The effect of rapid irregular rhythms as seen in auricular fibrillation. J. Clin. Invest., 1926-27, 3, 435.

13. Gross, L., Mendlowitz, M., and Schauer, G., Hemodynamics following experimental coronary occlusion in dogs. Proc. Soc. Exper. Biol. and Med., 1936, 35, 446.

14. Yeomans, A., Porter, R. R., and Swank, R. L., Observations on certain manifestations of circulatory congestion produced in dogs by rapid infusion. $\mathrm{J}$. Clin. Invest., 1943, 22, 33.

15. Fishberg, A. M., Heart Failure. Lea and Febiger, Philadelphia, 1937, p. 248.

16. Dietrich, S., and Schwiegk, H., Die Bedeutung der Venendruckregulation für die Kreislaufpathologie. Klin. Wchnschr., 1934, 13, 514.

17. Richards, D. W., Jr., Caughey, J. L., Cournand, A., and Chamberlain, F. L., Intravenous saline infusion as a clinical test for right-heart and left-heart failure. Tr. A. Am. Physicians, 1937, 52, 250.

18. Murphy, F. D., Correll, H., and Grill, J. C., The effects of intravenous solutions on patients with and without cardiovascular defects. J. A. M. A., 1941, 116, 104.
19. Olmer, D., Jouve, A. X., and Vague, J., Une épreuve functionnelle de la circulation de retour. Presse méd., 1938, 46, 1233.

20. Starr, I., and Rawson, A. J., Rôle of the "static blood pressure" in abnormal increments of venous pressure especially in heart failure. I. Theoretical studies on an improved circulation schema whose pumps obey Starling's law of the heart. Am. J. M. Sc., 1940, 199, 27.

21. Meek, W. J., and Eyster, J. A. E., Reactions to hemorrhage. Am. J. Physiol., 1921, 56, 1.

22. Walcott, W. W., Blood volume in experimental hemorrhagic shock. Am. J. Physiol., 1945, 143, 247.

23. Asmussen, E., Christensen, E. H., and Nielsen, M., Uber die Kreislaufinsuffizienz in stehender Stellung bei normalem arteriellen Druck und herabgesetztem Minutenvolumen. Skandinav. Arch. f. Physiol., 1939, 81, 214.

24. Landis, E. M., and Gibbon, J. H., Jr., The effects of temperature and of tissue pressure on the movement of fluid through the human capillary wall. J. Clin. Invest., 1933, 12, 105.

25. Perera, G. A., and Berliner, R. W., The relation of postural hemodilution to paroxysmal dyspnea. $\mathrm{J}$. Clin. Invest., 1943, 22, 25.

26. Kaltreider, N. L., and Meneely, G. R., The effect of exercise on the volume of the blood. $\mathrm{J}$. Clin. Invest., 1940, 19, 627.

27. Meneely, G. R., and Kaltreider, N. L., Study of the volume of the blood in congestive heart failure. Relation to other measurements in 15 patients. J. Clin. Invest., 1943, 22, 521.

28. Altschule, M. D., The pathological physiology of chronic cardiac decompensation. Medicine, 1938, 17, 75.

29. Ernst, C., Beitrag zur Frage des Kreislaufes bei der Polycythaemia vera. Ztschr. f. klin. Med., 1930, 114, 757.

30. Loeb, R. F., Atchley, D. W., Richards, D. W., Jr., Benedict, E. M., and Driscoll, M. E., On the mechanism of nephrotic edema. J. Clin. Invest., 1932, 11, 621 .

31. White, P. D., Heart failure; Wesley M. Carpenter Lecture. Bull. New York Acad. Med., 1942, 18, 18.

32. Ott, A., Uber Blutmenge und Knochenmarksbefund bei Herzinsuffizienz. Deutsches Arch. f. klin. Med., 1939, 185, 176.

33. Marsovsky, P. v., Uber die Funktion der Arteriolen bei decompensierten Herzkranken. Ztschr. f. Kreislaufforsch., 1942, 34, 446.

34. Harrison, T. R., Failure of the Circulation. Williams and Wilkins, Baltimore, 1939.

35. Levine, S. A., Some harmful effects of recumbency in the treatment of heart disease. J. A. M. A., 1944, 126,80 . 